\title{
Calculation of The Intracranial Volume in Gazelles (Gazella subgutturosa) by Stereology and Computed Tomography
}

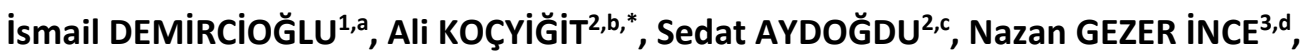 \\ Bestami YILMAZ ${ }^{1, e}$
}

\author{
${ }^{1}$ Department of Anatomy, Faculty of Veterinary Medicine, Harran University, Şanlıurfa, Turkey \\ ${ }^{2}$ Department of Anatomy, Faculty of Veterinary Medicine, Selcuk University, Konya, Turkey \\ ${ }^{3}$ Department of Anatomy, Faculty of Veterinary Medicine, Istanbul University-Cerrahpasa, Istanbul, Turkey \\ aORCID: 0000-0002-0724-3019, ' ORCID: 0000-0002-9354-7480, 'ORCID: 0000-0002-9354-3519, \\ dORCID: 0000-0003-1627-5757, e ORCID: 0000-0002-0901-3129
}

\begin{abstract}
The danger of extinction faced by the gazelles, which show a broad geographical distribution, in recent times and inclusion of the gazelles in the conservation list of IUCN indicate the importance and necessity of the studies on continuity of the species. In this context, the determination of intracranial volume is clinically essential for the breed and sexual dysmorphism. In the present study the crania of 11 gazelles ( 5 male and 6 female gazelles) (Gazella subgutturosa) were used. The cranium of the gazelles were scanned at $80 \mathrm{kV}, 200 \mathrm{~mA}, 639 \mathrm{mGY}$, and $0.625 \mathrm{~mm}$ section thickness using 64-slice Multi-Detector Computed Tomography (MDCT). The intracranial volume of the gazelles was estimated using computed tomography sections according to Cavalieri's Principle. Three-dimensional models of the intracranial area were created using MIMICS 20.1 Software, the software calculated intracranial volume. The obtained results were statistically tested in terms of both methods and sexual dimorphism. The study results revealed that crania showed no difference between sexes $(P>0.05)$. No difference was detected between the two methods in statistical analysis of the intracranial volumes calculated using stereology and CT models. Consequently, it was considered that the use of intracranial volumes of the gazelles would contribute to the clinical sciences concerning detection, diagnosis and progression of the diseases.
\end{abstract}

Keywords: 3D modeling, Gazelle subgutturosa, Intracranial volume, Neurocranium, Stereology.

\section{Ceylanlarda (Gazella subgutturosa) Intracranial Hacmin Stereoloji ve Bilgisayarlı Tomografi ile Hesaplanması}

Özet: Geniş bir coğrafyada yaygınlık gösteren ceylanlar, son zamanlar neslin tükenme tehlikesiyle karşı karşıya kalması ve IUCN tarafından korunmaya alınması, türün devamı için çalışmaların önemli ve gerekli olduğunu göstermektedir. Bu bağlamda intracranial hacmin bilinmesi klinik yönden, ırk ve cinsiyet ayırımı için önemlidir. Çalışmamızda 11 adet (5 erkek, 6 dişi) ceylan (Gazella Subgutturosa) craniumu kullanıldı. Ceylanların craniumları 64-dedektörlü Multi Dedektör Bilgisayarlı Tomografi (MDCT) cihazında $0.625 \mathrm{~mm}$ kesit kalınlığında, 80 kV, $200 \mathrm{~mA}$ ve $639 \mathrm{mGY}$ ile tarandı. Ceylanların cranial hacimleri bilgisayarlı tomografi kesitleri kullanılarak Cavalieri prensibi ile ölçüldü. Ayrıca MIMICS 20.1 software yazılımı kullanılarak intracranial alanın 3 boyutlu modelleri elde edildi ve program üzerinde hacim hesaplandı. Elde edilen sonuçlar hem yöntemler hem de cinsiyet ayırımı açısından istatistiksel olarak test edildi. Çalışmada craniumların cinsiyetler arasında farklılık göstermediği tespit edildi ( $P>0.05)$. Ayrıca, stereoloji ve BT modelleri ile hesaplanan cranial hacimlerin istatistiksel olarak incelenmesinde iki metot arasında fark olmadığı tespit edilmiştir. Sonuç olarak, ceylanların intracranial hacimlerinin kullanılarak hastalıkların tanı, tespit ve seyri açısından klinik bilimlere katkı sağlayacağı düşünülmektedir.

Anahtar Kelimler: 3B modelleme, Gazelle subgutturosa, intracranial hacim, Neurocranium, Stereoloji.

\section{Introduction}

Gazella subgutturosa is a species that exhibits distribution in broad geography extending from Mongolia to Turkey and inhabits at an altitude up to 3500 meters (Heptner et al., 1998; Mallon and Kingswood, 2001). Because of its decreasing population, Gazella subgutturosa was included in the red list of the International Union for Conservation of Nature and Natural Resources (IUCN) and classified as vulnerable (IUCN, 2017).

Cranium is a structure formed mainly by paired bones covering sensory organs such as taste, antler, scent, vision, and balance (Evans ve De Lahunta., 2013; König ve Liebich., 2020). Its health condition is affected parallelly with the normal functioning of the vital organs it contains (Din et al., 2020; Schofield et al., 1995). The cranial cavity involves the brain, liquor cerebrospinalis, blood vessels and is surrounded by cavum cranii (Evans ve De Lahunta., 2013; König ve Liebich., 2020; Rodrigues et al., 2017). It is clinically significant to know the intracranial volume and cranial capacity, and brain volume should be known for diagnosis and follow- 
up of some neurodegenerative diseases (Schofield et al., 1995). Knowing the cranial capacity may be used in the breed and sexual dimorphism (Rushton, 1994). Different methods such as stereology, planimetry, anthropometry, plant seeds, magnetic resonance, and computed tomography imaging are applied to calculate intracranial volume (Acer et al., 2007; Choudhary et al., 2015; Ertekin et al., 2016; Mendoza et al., 2014).

Stereology is applied in various fields such as anatomy, cell biology, geology, and botany and is one of the practical methods to analyze several two-dimensional sections randomly obtained from three-dimensional solid materials (Baddeley, 1991; Russ ve Dehoff, 2000). Cavalieri's Principle is a method applied to calculate the total volume of the irregular-shaped structures and organs such as the brain using randomly obtained parallel and equal sections (Canan et al., 2002; Gundersen et al., 1988). This method is also used with imaging methods such as Computed Tomography (CT) and Magnetic Resonance Imaging (MRI) (Odacl et al., 2005). The measurement of tumor volumes using this method before and after treatment provides advantages to the physicians regarding the progression of the diseases (Ak et al., 2010).

CT is one of the medical imaging methods that was developed in 1970s and rapidly advanced. It processes the data collected from the area X-ray passes through in the computer and creates sectional images. Three-dimensional (3D) models are created using 2-dimensional (2D) sectional images obtained by CT sections, and consequently, studies can be conducted on these models (Romans, 2018; Wang, 2009).

The present study aimed to calculate the volume of the cranial cavity in the gazelles (Gazella
Subgutturosa) utilizing 3-dimensional models obtained by the stereological and CT sections and to calculate statistically the difference between the methods in terms of sex according to the obtained results. It was also aimed to contribute to the limited literature in this field by comparing the results of the present study with the intracranial volumes identified in the studies on different breeds and species.

\section{Materials and Method}

In the present study, the crania of 11 adult gazelles (five males, six females) (Gazella Subgutturosa) were used. The General Directorate of Nature Conservation and National Parks Turkey approved using the cadavers (Approval no: 2017/209842) and the study had approval from Harran University Animal Experimentation Local Ethics Committee (Approval no: 2018/006-11).

The gazelles' cranium was scanned at $80 \mathrm{kV}$, $200 \mathrm{~mA}, 639 \mathrm{mGY}$, and $0.625 \mathrm{~mm}$ section thickness using a 64-slice Multi-Detector Computed Tomography (MDCT). Prokop (2003) and Kalra (2004) were accepted as references for scanning and dose protocols. The reconstruction of the cranium was performed by MIMICS 20.1 (The Materialise Group, Leuven, Belgium) software from the images recorded in the format of DICOM (Digital Imaging and Communications in Medicine).

The margins of the intracranial cavity were determined using the sections taken from CT in MIMICS 20.1 software. The sections of the determined area were used to create 3-dimensional models. The volumetric values of the created models were recorded (Figure $1 \mathrm{~A}$ ).
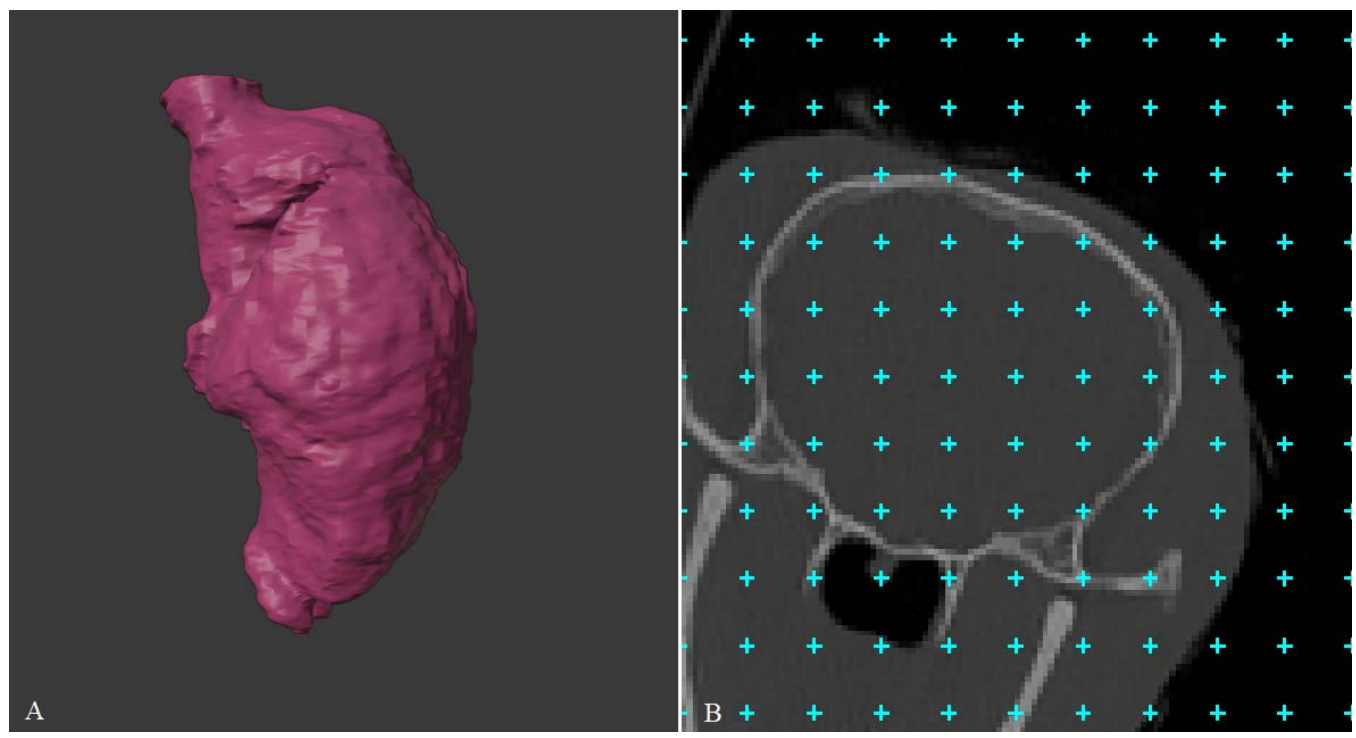

Figure 1: 3D modeling of the intracranial cavity (A), A point-counting grid that superimposed on CT slice (B). 

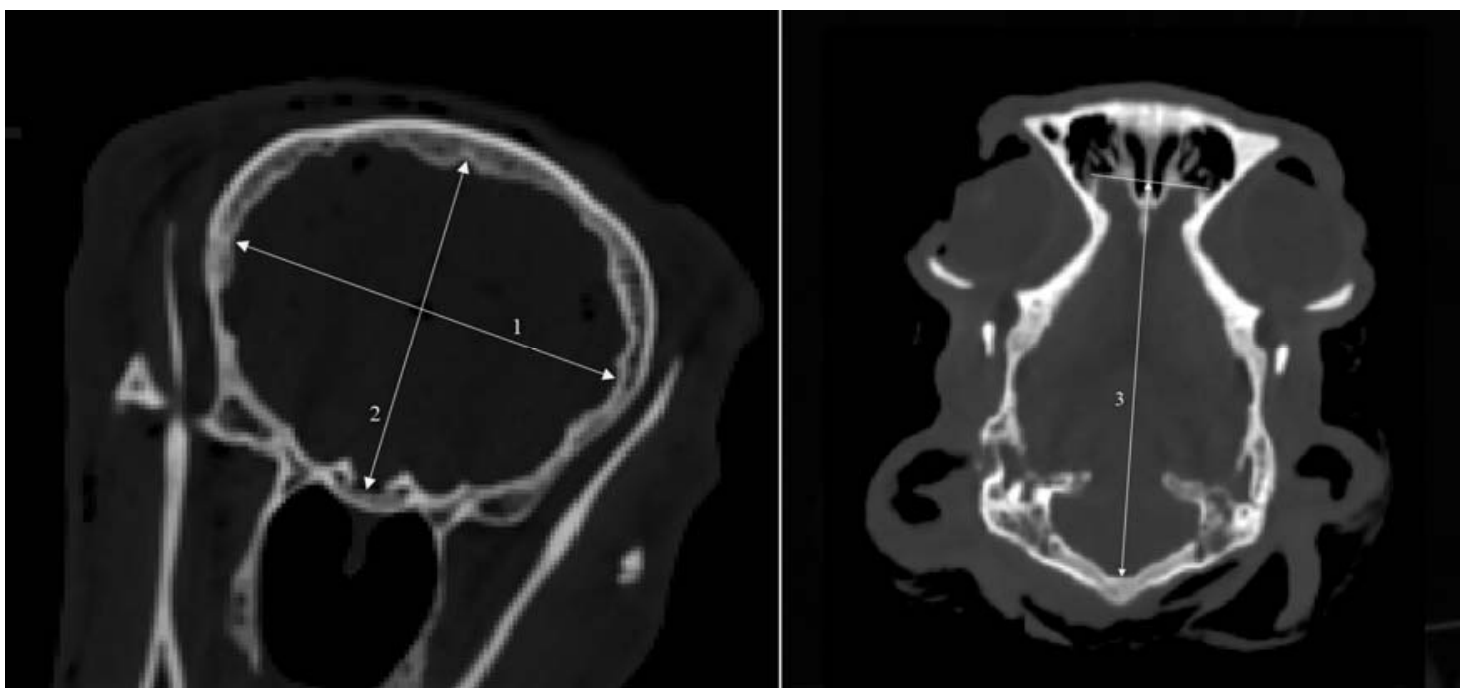

Figure 2: Maximum width of the cranial cavity (1), Maximum height of cranial cavity (2), Maximum length of the cranial cavity (3).

The cranial margins were detected by stereology method, and 12 sections were obtained in each gazelle by using a systematic random sampling method from CT sections of these sites. The obtained section images were counted with 81 $\mathrm{mm}^{2}$ intervals by using the "Grid" option on the "ImageJ" software and calculated according to Cavalier's principle. The same procedure was repeated three times to be calculated at different times (Figure 1B). Intracranial volumes were estimated using the following equation:

$$
V=\sum p \times t \times a(p)
$$

Measurements are taken from the cranial cavity: Figure 2: Measurement of the cranial cavity. 1- MWCC: Maximum width of the cranial cavity, 2- MHCC: Maximum height of the cranial cavity, 3- MLCC: Maximum length of the cranial cavity

Index 1 (Cranial cavity index): maximum width of the cranial cavity $\times 100 /$ maximum length of cranial cavity

Index 2 (Length width index): maximum length of cranial cavity / maximum width of the cranial cavity (Kunzel et al., 2003; Onar et al., 2002).

The coefficient of error (CE) was estimated by taking Sahin et al., (2001), Roberts et al., (1993), and Gundersen and Jensen (1987) as reference.

Statistical analysis of the data was carried out using SPSS 21.0 software. The data were found to be normally distributed. An independent t-test was applied to determine the difference between sexes, while paired t-test was used to detect the difference between the methods.

\section{Results}

Table 1 shows the total mean intracranial volumes obtained by stereology and computed tomography. The calculation of total volumes of males and females by computed tomography and stereological methods is presented in Table 2 . The study results revealed that female gazelles had higher total intracranial volume than the males; however, no statistical difference was found between sexes $(P>0.05)$. Although the total mean intracranial volume was higher in the models obtained by computed tomography, no statistical difference was determined between the two methods $(P>0.05)$. Although there was a difference between Index 1 and Index 2, no statistical difference was detected.

Table 1: Comparison of intracranial volume estimated by the two methods.

\begin{tabular}{lcllllll}
\hline Method & $\mathbf{N}$ & Minimum $\left(\mathbf{c m}^{3}\right)$ & Maximum $\left(\mathbf{c m}^{3}\right)$ & Mean & Std. dev. & Sig. & Correlation \\
\hline Computed Tomography & 11 & 68.20 & 87.81 & 80.51 & 6.89 & 0.14 & 0.98 \\
Stereology & 11 & 67.03 & 88.10 & 79.88 & 7.46 &
\end{tabular}


Table 2: Estimation of intracranial volume by different methods and genders.

\begin{tabular}{lllllllll}
\hline Method & Gender & $\mathrm{n}$ & Minimum $\left(\mathrm{cm}^{3}\right)$ & Maximum $\left(\mathrm{cm}^{3}\right)$ & Mean & Std. dev. & Sig & CE \\
\hline Stereology & Female & 6 & 67.03 & 87.67 & 80.80 & 8.01 & 0.74 & 0.03 \\
& Male & 5 & 67.60 & 88.10 & 78.77 & 7.50 & 7.21 & 0.85 \\
Computed & Female & 6 & 68.34 & 87.81 & 81.38 & 7.03 \\
Tomography & Male & 5 & 68.20 & 87.56 & 79.48 & 7.16 &
\end{tabular}

Although the cranial cavity was longer in male gazelles, no statistical difference was found between the sexes $(P>0.05)$. A difference was present between indices calculated based on cranial cavity parameters; however, no statistical difference was observed $(P>0.05)$.

Table 3: Parameter of the cranial cavity.

\begin{tabular}{llllllll}
\hline Parameter & & $\mathrm{n}$ & Minimum $(\mathrm{mm})$ & Maximum $(\mathrm{mm})$ & Mean & Std. dev. & Sig \\
\hline MWCC & Female & 6 & 50.77 & 54.61 & 53.40 & 1.38 & 0.28 \\
& Male & 5 & 50.81 & 54.25 & 52.41 & 1.48 & \\
\hline MHCC & Female & 6 & 40.27 & 47.21 & 43.39 & 3.10 & 0.80 \\
& Male & 5 & 41.52 & 45.98 & 42.99 & 1.73 & \\
\hline MLCC & Female & 6 & 73.47 & 81.45 & 76.83 & 3.17 & 0.14 \\
& Male & 5 & 74.04 & 87.58 & 81.15 & 5.64 & \\
\hline Index 1 & Female & 6 & 65.34 & 73.89 & 69.63 & 3.89 & 0.63 \\
& Male & 5 & 60.49 & 68.63 & 64.77 & 3.65 & \\
\hline Index 2 & Female & 6 & 1.35 & 1.53 & 1.43 & 0.08 & 0.61 \\
& Male & 5 & 1.46 & 1.65 & 1.54 & 0.08 & \\
\hline & & & & & & &
\end{tabular}

\section{Discussion}

Cavalieri's Principle is one of the methods preferred in calculation of the volumes of the geometrical objects of different shapes with high accuracy and is also used together with different imaging techniques such as MRI or CT (Roberts et al., 1993; Sahin and Ergur, 2005; Yılmaz and Tuğrul, 2019).

The present study aimed to calculate the total intracranial volumes by the models obtained from the computed tomography sections and stereological method. High compatibility was identified between these two methods. Dello et al. (2007) stated in their study that ImageJ software could be used in stereological calculations. Rodrigues et al. (2017) conducted a study on goats and determined that the volumes of the intracranial cavity were $123.94 \pm 9.84 \mathrm{~cm}^{3}$ and $114.64 \pm 12.72 \mathrm{~cm}^{3}$ in male and female goats, respectively. No statistical difference was identified between the sexes, similarly with the present study. Sarma (2006) studied 45 Kagani goats without sex discrimination and calculated intracranial volume as
$113 \pm 0.84 \mathrm{~cm}^{3}$. Logan and Clutton-Brock (2013) calculated the endocranial volumes of the red deers as $370 \pm 39 \mathrm{~cm}^{3}$ using computed tomography and software. In addition, endocranial volume measurements obtained by the bead method and computed tomography scans revealed similar results. Chanpanitkitchote et al. (2015) carried out their study on some different species without sex discrimination. They calculated the cranial volumes as $0.172 \mathrm{lt}, 0.314 \mathrm{lt}, 0.171 \mathrm{lt}, 0.162 \mathrm{lt}, 0.197 \pm 0.013$ It, and $0.145 \pm 0.009$ It in Sitatunga, Malayan tapir, chital gazelles, Muntiacus muntjac, Grant's gazelle, and sheep, respectively. Choudray and Singh (2015), who used cotton to calculate cranial capacity in their morphometric study on the crania of the blackbucks, estimated the cranial capacities of female and male antelopes to be $106.33 \pm 0.04 \mathrm{~cm}^{3}$ and $109.33 \pm 1.08 \mathrm{~cm}^{3}$, respectively, and they carried out no statistical comparison. Karimi et al, (2011) calculated the cranial capacity of Mehraban sheep as $130.86 \pm 11.55 \mathrm{~cm}^{3}$ using rice grains, and sexes were not considered. Ömer and Alpak (2012) calculated the cranial capacity of female and male curly-fleeced sheep to be respectively $133.89 \pm 10.82$ $\mathrm{cm}^{3}$ and $136.10 \pm 17.281 \mathrm{~cm}^{3}$ in their study. They 
noted parallelly with the present study that no difference was detected between the sexes (36). Tohifidar et al. (2020) determined the cranial cavity as $423 \pm 48.2 \mathrm{~cm}^{3}$ using the computed tomography and stereology approach in Saanen goats.

Regedon et al. (1991) calculated the cranial volumes of the dogs from different breeds using computed tomography. They stated that sexes could be differentiated based on cranial volume at the rate of $99 \%$. No difference was identified between the sexes in the present study.

In the present study, we tried to calculate the cranial cavity volume in the gazelles (Gazella subgutturosa) using different methods. In the present study, there was no statistical difference between stereology and computed tomography concerning the calculation of cranial cavity, and similar results were obtained using the two methods.Therefore one of these two methods can be used in the studies to be conducted in these fields. It is thought that the present study would contribute to the studies on the intracranial field and subjects such as the clinical approach.

\section{References}

Acer N, Sahin B, Bas O, Ertekin T, Usanmaz M, 2007: Comparison of three methods for the estimation of total intracranial volume: stereologic, planimetric, and anthropometric approaches. Ann Plas Surg, 58 (1), 48-53.

Ak G, Metintas M, Metintas S, Yildirim H, Ozkan R, Ozden $\mathrm{H}$, 2010: Three-dimensional evaluation of chemotherapy response in malignant pleural mesothelioma. Eur J Radiol, 74 (1), 130-135.

Baddeley A, 1991: Spatial Statistics and Digital Image Analysis, 181-216. National Research Council, Washington DC, USA.

Canan S, Şahin B, Odacı E, Ünal B, Aslan H, Bilgiç S, Kaplan $S$, 2002: Toplam hacim, hacim yoğunluğu ve hacim oranlarının hesaplanmasında kullanılan bir stereolojik yöntem: Cavalieri prensibi. Turk Klin J Med, 22, 7-14.

Chanpanitkitchote $\mathrm{P}$, Tangphokhanon W, Nomsiri R, Kaewmong P, Kongteung P, Nganvongpanit K, 2015: Ratio of cranial and skull volumes in 25 mammalian species. Vet Integr Sci, 13 (3), 165-177.

Choudhary OP, Singh I, 2015: Morphometrical Studies on the Skull of Indian Blackbuck (Antelope cervicapra). J Morphol, 33 (3), 868-876.

Choudhary OP, Singh I, Bharti SK, Mohd KI, Sathapathy S, Mrigesh M, 2015: Gross and Morphometrical Studies on Mandible of Blackbuck (Antelope cervicapra). J Morphol, 33 (2), 428-432.

Dello SA, van Dam RM, Slangen JJ, van de Poll MC, Bemelmans $\mathrm{MH}$, Greve JWW, Beets-Tan RGH, Wigmore SJ, Dejong, $\mathrm{CH}, 2007$ : Liver volumetry plug and play: do it yourself with ImageJ. World J Surg, 31 (11), 2215-2221
Din S, Masood S, Zaneb H, Rehman H, Ashraf S, Khan I, Shah M, Hadi SA, 2020: Gross and clinical anatomy of the skull of adult chinkara (Gazella bennettii). Pak J Zool, 52 (5), 123-1733.

Ertekin T, Acer N, Köseoğlu E, Zararsız G, Sönmez A, Gümüş K, Kurtoğlu E, 2016: Total intracranial and lateral ventricle volumes measurement in Alzheimer's disease: A methodological study. J Clin Neurosci, 34, 133-139.

Evans HE, De Lahunta A, 2013: Miller's anatomy of the dog. 4th ed., Elsevier Health Sciences., Missouri, USA

Gundersen HJG, Bendtsen TF, Korbo L, Marcussen N, Møller A, Nielsen K, Nyengaard B, Pakkenberg B, Sørensen FB, Vesterby A, West MJ, 1988: Some new, simple and efficient stereological methods and their use in pathological research and diagnosis. APMIS, 96 (1-6), 379-394.

Gundersen HJG, Jensen EB, 1987: The efficiency of systematic sampling in stereology and its prediction. J Microsc, 147 (3), 229-263.

Haluk Ö, Alpak H, 2012: Kıvırcık Koyunlarında Stereolojik Metotla Cranial Hacim Hesaplanması ve Bunun Kraniyometrik Ölçümleri ile İlişkisi. İstanb Univ Vet Fak Derg, 38 (2), 107-119.

Heptner VG, Nasimovich AA, Bannikov AG, 1988: Mammals of the Soviet Union. Artiodactyla and Perissodactyla. Smithsonian Institution Libraries and The National Science Foundation, 1:1-1147 (translation from Russian).

IUCN SSC Antelope Specialist Group. 2017. Gazella subgutturosa. The IUCN Red List of Threatened Species 2017: e.T8976A50187422. https://dx.doi.org/10.2305/IUCN.UK.20172.RLTS.T8976A50187422.en. Date of access; 05 September 2021.

Kalra MK, Maher MM, Toth TL, Hamberg LM, Blake MA, Shepard JA, Saini S, 2004: Strategies for CT radiation dose optimization. Radiology, 230 (3), 619-628.

Karimi I, Onar V, Pazvant G, Hadipour M, Mazaheri Y, 2011: The cranial morphometric and morphologic characteristics of Mehraban sheep in Western Iran. Glob Vet, 6 (2), 111-117.

König HE, Liebich HG, 2020: Veterinary anatomy of domestic animals: Textbook and colour atlas. Georg Thieme Verlag, New York, USA

Künzel W, Breit S, Oppel M, 2003: Morphometric investigations of breed-specific features in feline skulls and considerations on their functional implications. Anat Histol Embryol, 32 (4), 218-223.

Logan CJ, Clutton-Brock TH, 2013: Validating methods for estimating endocranial volume in individual red deer (Cervus elaphus). Behav Processes, 92, 143-146.

Mallon DP, Kingswood SC, 2001: Antelopes. Part 4: North Africa, the Middle East, and Asia. Global Survey and Regional Action Plans. SSC Antelope Specialist Group, IUCN, Gland, Switzerland and Cambridge, England

Mendoza CS, Safdar N, Okada K, Myers E, Rogers G F, Linguraru MG, 2014: Personalized assessment of craniosynostosis via statistical shape modeling. Med Image Anal, 18 (4), 635-646. 
Odacı E, Bahadır A, Yıldırım Ş, Şahin B, Canan S, Baş O, Bilgiç S, KaplanS, 2005: Cavalieri prensibi kullanılarak bilgisayarlı tomografi ve manyetik rezonans görüntüleri üzerinden hacim hesaplanması ve klinik kullanımı. Türkiye Klin J Med, 25 (3), 421-428.

Onar V, Kahvecioglu KO, Çebi V, 2002: Computed tomographic analysis of the cranial cavity and neurocranium in the German shepherd dog (Alsatian) puppies. Vet Arh, 72 (2), 57-66.

Prokop M, 2003: General principles of MDCT. Eur J Radiol 45:4-10.

Regodon S, Franco A, Garin JM, Robina A, Lignereux Y, 1991: Computerized tomographic determination of the cranial volume of the dog applied to racial and sexual differentiation. Cells Tissues Organs, 142 (4), 347-350.

Roberts N, Cruz-Orive LM, Reid NMK, Brodie DA, Bourne M, Edwards RHT, 1993: Unbiased estimation of human body composition by the Cavalieri method using magnetic resonance imaging. J Microsc, 171 (3), 239-253.

Rodrigues RTS, Matos WCG, Walker FM, Costa FS, Wanderley CWS, Neto JP, Faria M D, 2017: Dimensions of the cranium and of the cranial cavity and intracranial volume in goats (Capra hircus LINNAEUS, 1758). J Morphol Sci, 27 (1), 6-10.

Romans L, 2018: Computed tomography for technologists: a comprehensive text. Lippincott Williams \& Wilkins.

Rushton JP, 1994: Sex and race differences in cranial capacity from International Labour Office data. Intelligence, 19 (3), 281-294.

Russ JC, Dehoff RT, 2000: Practical stereology. Kluwer Academic/Plenum Publlishers, New York, USA.
Sahin B, Aslan H, Unal B, Canan S, Bilgic S, Kaplan S, Tumkaya L, 2011: Brain volumes of the lamb, rat and bird do not show hemispheric asymmetry: a stereological study. Image Anal Stereol, 20 (1), 9-13.

Sahin B, Ergur H, 2006: Assessment of the optimum section thickness for the estimation of liver volume using magnetic resonance images: a stereological gold standard study. Eur J Radiol, 57 (1), 96-101.

Sarma K, 2006: Morphological and craniometrical studies on the skull of Kagani goat (Capra hircus) of Jammu region. Int J Morphol, 24 (3), 449-55.

Schofield PW, Mosesson RE, Stern Y, Mayeux R, 1995: The age at onset of Alzheimer's disease and an intracranial area measurement: a relationship. Arch Neurol, 52 (1), 95-98.

Tohidifar M, Goodarzi N, Masoudifard M, 2020: Anatomy of the head in the Saanen goat: a computed tomographic and cross-sectional approach. Anat Sci Int, 95 (3), 408-419.

Wang H, 2009: Three-dimensional medical CT image reconstruction. In 2009 International Conference on Measuring Technology and Mechatronics Automation. Zhangjiajie, Hunan, China, Vol. 1, pp. 548-551.

Yılmaz O, Tuğrul T, 2019: Van kedilerinde total beyin hacminin bilgisayarlı tomografi görüntüleri kullanılarak hesaplanması. Eurasian J Bio Chem Sci, 2 (2), 42-46.

*Correspondence: Ali KOÇYiĞiT

Selçuk University Faculty of Veterinary, Department of Anatomy, Selçuklu, Konya.

e-mail: kcygtali@outlook.com 